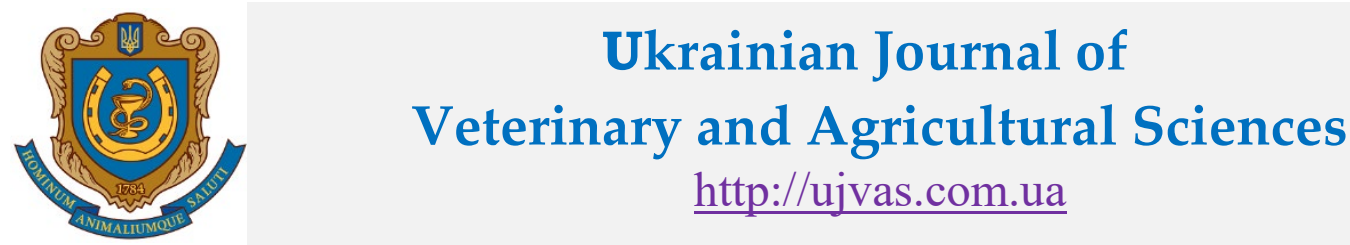

Stepan Gzhytskyi National University of Veterinary Medicine and Biotechnologies Lviv

\begin{tabular}{l|l|l} 
original article & UDC 619:618:616.615.32:636.2 & doi: 10.32718/ujvas2-3.03
\end{tabular}

Volume 2

Number 3

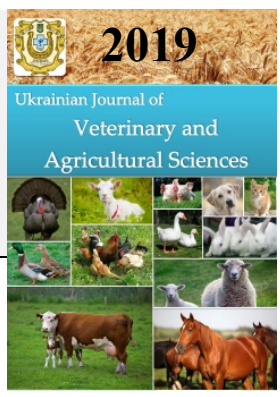

\title{
Selection of the optimal composition of vegetable oil and chlorophyllipt oil components
}

\author{
R. M. Sachuk ${ }^{1}$, Ya. S. Stravsky ${ }^{2}$, YU. V. Horyuk ${ }^{3}$, O. A. Katsaraba ${ }^{4}$, S. V. Zhyhalyuk ${ }^{1}$ \\ ${ }^{1}$ Research Epizootology Station IVM NAAS, Knyazya Volodymyra Str., 18, Rivne, 33028, Ukraine \\ ${ }^{2}$ I. Horbachevsky Ternopil National Medical University, Freedom Square, 1, Ternopil, 46001, Ukraine \\ ${ }^{3}$ State Agrarian and Technical University Podilia, Schevchenko Str., 13, Kamianets-Podilskyi, 32300, Ukraine \\ ${ }^{4}$ Stepan Gzhytskyi National University of Veterinary Medicine and Biotechnologies, Pekarska, Str., 50, Lviv, 79010, Ukraine
}

\begin{abstract}
Article info
Received 28.10.2019

Received in revised form 02.12 .2019

Accepted 03.12.2019

Correspondence author

Roman Sachuk

Tel.: +38-097-671-90-63

E-mail: sachuk.08@ukr.net

Abstract

Investigate the antimicrobial properties of various concentrations of vegetable essential oils in combination with an oil solution of chlorophyllipt as possible ingredients for ointments for wounds. Microbiological tests were performed according to standard methods using E. coli test cultures, S. aureus, Str. agalactiae and P. fluorescens. The results of studies of antibacterial activity of both individual ingredients and their combinations are presented, namely: $4 \%$ essential oil of Siberian pine, $2 \%$ essential oil of eucalyptus, $1.5 \%$ essential oil of cloves, $1.5 \%$ of essential oil of cedar, $2.0 \%$ tea tree essential oil and $1.0 \%$ chlorophyllipt oil solution. Bacteria, which are usually typical agents of wound infections, have been found to be quite sensitive to the drugs tested. High activity of essential oils and oily solution of chlorophyllipt with respect to $E$. coli and $S$. aureus was revealed. In particular, a $1.0 \%$ oily solution of chlorophyllipt caused staphylococcal growth retardation zones whose diameters were 1.4 times larger than the antibiotic clindamycin. It was determined that representatives of gram-negative microflora were more sensitive to the investigated essential oils and chlorophyll. The optimal composition of the experimental drug called "Ointment for wounds" is offered. The results of preclinical testing showed a sufficiently high efficiency compared to traditional means. The results obtained with regard to antimicrobial activity indicate the prospect of using preparations based on the essential oil of Siberian pine, eucalyptus, carnation, cedar, tea tree and oil solution of chlorophyllipt for the treatment of skin diseases in animals. This data will help to develop new effective and safe veterinary treatments for wound care.

2019 Sachuk R. M. et al. This is open-access article distributed under Attribution License, which permits unrestricted use, distribution, reproduction in any medium provided the original author and source are credited.

\section{$(\mathrm{cc}) \mathrm{Br}$}

Contents

1. Introduction

Key words: essential oils, chlorophyllipt, clindamycin, antimicrobial activity, test cultures, skin.

3. Results and discussion ...... 12

4. Conclusions ................. 13

References ...................... 13

Citation:

Sachuk, R. M., Stravsky, Ya. S., Horyuk, YU. V., Katsaraba, O. A., \& Zhyhalyuk, S. V. (2019). Selection of the optimal composition of vegetable oil and chlorophyllipt oil components. Ukrainian Journal of Veterinary and Agricultural Sciences, 2(3), 11-14.

\section{Introduction}

The pharmaceutical market of veterinary dermatological medicines of Ukraine is filled mainly with preparations of foreign production. Multicomponent preparations, which are in the assortment, mainly consisting of antibiotics and glucocorticoids, they do not always adequately affect all parts of the pathological process. The search for highly effective and environmentally sound therapeutic and prophylactic agents used in skin diseases in animals has received considerable attention from both domestic and foreign researchers (Shaheen et al., 2016; Horiuk, 2018). The trend of recent times is the use of biologically active components of plant origin as an alternative to antibiotic therapy (Tamminen et al., 2018; Vorobets et al., 2018). Successfully selected combinations of essential oils are often no less effective than synthetic antibiotics, and the risk of resistant strains of microorganisms is reduced (Queiroga et al., 2018; Santos et al., 2019). And the cost of veterinary drugs and medical measures with the use of raw materials of natural origin is more attractive. One of the important benefits of herbal medicine treatment is their low toxicity and minimal side effect (Hong, et al., 2004; Okmen, et al., 2016). In addition, herbal remedies can include a combination of many compounds that best meet the intended therapeutic goals (Okmen, et al., 2016). In dermatology, the combination of antimicrobial, anti-inflammatory, immunomodulatory and reparative properties is the main criterion for the selection of biologically active substances of plant origin (Wolski et al., 2017). Among the herbal remedies, the above pharmacological characteristics include Siberian pine essential oil (Shpatov et al., 2017; Carrión-Prieto et al., 2018), eucalyp- 
tus (Harkat-Madouri et al., 2015; Adnan, 2019), carnations (Santa Packyanathan \& Prakasam, 2017), cedar (Bennouna et al., 2018), tea tree (Smith et al., 2014; Li et al., 2016) and chlorophyll. This was the basis for a more detailed study of them and the creation of an experimental drug in the form of ointments. It was important to find the optimal formulation of ointment, the concentration of active substances.

The goal of the work. Investigate the antimicrobial properties of various concentrations of vegetable essential oils in combination with an oil solution of chlorophyllipt as possible constituents of ointments for wounds.

\section{Materials and methods}

Laboratory preclinical tests for the selection of the optimal composition of the preparations were carried out in the laboratory of experimental and analytical methods of research of the Epizootology Research Institute of the Institute of Nautical Sciences, microbiological studies - in the laboratory of veterinary sanitary and animal products expertise of the Ternopil Research Institute.

Various amounts of essential oils of Siberian pine (Oleum Pini), eucalyptus (Oleum Eucalypti), carnations (Oleum Caryophyllata), cedar (Oleum Cup) were introduced into the ointment base $(50 \%$, which is made on the basis of PEG400: PEG-1500), a tea tree (Oleum malaleuca alternifolia) and an oil solution of chlorophyllipt (Extractum chlorophyllipt, manufactured by Leko Style, Russia) containing a mixture of chlorophylls from eucalyptus leaves. Clincamycin ointment (Akrikhin CFC, Russia) containing a semisynthetic antibiotic clindamycin from the lincosamide group was used as a reference comparator in preclinical studies.

Determination of the minimum bactericidal concentration on planktonic microorganisms was performed according to standard methods (European committee on antimicrobial susceptibility..., 2015; 2017) using the test cultures of the following microorganisms: gram-negative bacteria Escherichia coli strain No. 078 (T. Escherich 1885) and Pseudomonas fluorescens ATCC 13525 (gram 1840) positive Staphylococcus aureus strain No. 209-P (Rosenbach 1884) and Streptococcus agalactiae (field strain isolated from cows with mastitis). Streptococcus Selective Agar medium (HiMedia, India) was used to isolate streptococci. The cultivation was carried out at $37{ }^{\circ} \mathrm{C}$, and the results were evaluated after $24-48$ hours. The identification of pure cultures was performed according to the morphological, tinctorial, cultural, biochemical properties described in the bacterial determinant.

To determine the sensitivity of planktonic microorganisms to the preparations were prepared suspensions of pure cultures, sieved suspensions in Petri dishes with MPA, using a punch No. 10 made in MPA wells and filled them with experimental samples of ointments. Petri dishes were incubated in a thermostat for 24 hours at $37{ }^{\circ} \mathrm{C}$, then visually evaluated the result by the diameter of the growth retardation of the microorganisms around the well. Up to $15 \mathrm{~mm}$ in diameter, microorganisms were considered to be practically insensitive, 16 to $20 \mathrm{~mm}$ were moderately sensitive, 21 to $25 \mathrm{~mm}$ were sensitive, $26 \mathrm{~mm}$ or more were highly sensitive to drug action.
Statistical processing of the results was performed by variational statistics methods using Statistica 6.0 (StatSoft Inc., USA). Nonparametric research methods were used (Wilcoxon, Mann - Whitney criteria). The arithmetic mean (x), standard error of the mean (SE) was determined. The difference between the two averages was considered statistically significant at $*-\mathrm{P}<0.05 ; * *-\mathrm{P}<0.01$; $* * *-\mathrm{P}<0.001$.

\section{Results and discussion}

Analysis of the effects of the test samples on bacterial test cultures showed that at concentrations $\geq 3.0 \%$ for Siberian pine oil, $\geq 2.0 \%$ for eucalyptus and $\geq 1.5 \%$ for carnation, cedar and tea tree, the ointment forms of the drugs reveal only background antistaphylococcal activity. Increasing the concentration of the preparations from 1.5 to $2.0 \%$ for the essential oil of tea tree, from $4 \%$ for pine anthrax and from $2.0 \%$ for eucalyptus, carnation, cedar contributes to the increase in the level of antistaphylococcal activity of the studied samples, as well as to broadening the spectrum their antimicrobial action (Table 1).

Used as a sample comparison with the antibiotic ointment clindamycin was effective against Escherichia coli, the growth retardation zone was $24.0 \pm 0.71 \mathrm{~mm}$; moderately effective for staphylococcus $(19.3 \pm 1.08 \mathrm{~mm})$ and streptococcus $(18.7 \pm 0.41 \mathrm{~mm})$, ineffective for the causative agent of pseudomonosis $(13.7 \pm 2.48 \mathrm{~mm})$.

In the next stage of the research, samples were tested containing minimal effective concentrations of essential oils for the test microorganisms in different combinations with an oil solution of chlorophyll. The following ingredients were found to be optimal: $4 \%$ of Siberian pine essential oil, $2 \%$ of eucalyptus and tea tree, $1.5 \%$ of cloves and cedar, and $1.0 \%$ of oily solution of chlorophyllipt, the rest being ointment. The bactericidal activity of the test specimens against Escherichia coli and cocci was 1.25 times higher than the results obtained for the comparison drug - ointment with the semi-synthetic antibiotic Clindamycin. Our experimental composition was called "Ointment for Wounds".

Comparative analysis of the antimicrobial activity of the experimental drug, called "Ointment for wounds" showed that the growth retardation zones for $E$. coli and $S$. aureus test cultures under the action of essential oils and chlorophyllipt oil solution were twice larger than under the comparison drug "Clindamycin $2 \%$ ointment" $(\mathrm{P} \leq 0.05)$ (Fig. 1). Growth retardation zones of test cultures Str. agactactiae and $P$. fluorescens were almost one and a half times larger than clindamycin-based ointment and were $(16.8 \pm 0.55)$ and $(12.1 \pm 0.55) \mathrm{mm}$, respectively.

Thus, the combination of biologically active compounds of vegetable origin, namely $4 \%$ Siberian pine essential oil, $2 \%$ eucalyptus essential oil, $1.5 \%$ clove essential oil, $1.5 \%$ cedar essential oil, $2.0 \%$ tea tree oil and $1.0 \%$ oily solution of chlorophyllipt has clear antimicrobial properties. These essential oils also have an anti-inflammatory, antifungal action, promote healing of wounds, which became the basis for their inclusion in the experimental drug under the trade name "Ointment for Wounds". For traditional drug "Clindamycin $2 \%$ ointment", which is currently used in veterinary practice, such properties are not characteristic. 
Table 1

Antimicrobial Activity of Different Concentrations of Essential Oils and Chlorophyllipt Oil, $\mathrm{M} \pm \mathrm{m}, \mathrm{n}=3$

\begin{tabular}{|c|c|c|c|c|c|}
\hline \multirow{2}{*}{ № Sample } & \multirow{2}{*}{$\begin{array}{c}\text { Content of } \\
\text { active substance, } \%\end{array}$} & \multicolumn{4}{|c|}{ Growth retardation zone, $\mathrm{mm}$} \\
\hline & & E. coli & S. aureus & Str. agalactiae & P. fluorescens \\
\hline \multicolumn{6}{|c|}{ Siberian pine essential oil } \\
\hline 1 & 2.0 & $13.0 \pm 0.71^{* * *}$ & $17.0 \pm 1.41$ & $17.0 \pm 0.71$ & $16.0 \pm 0.71$ \\
\hline 2 & 3.0 & $19.0 \pm 0.71^{* *}$ & $17.3 \pm 1.47$ & $17.7 \pm 0.41$ & $17.7 \pm 0.41$ \\
\hline 3 & 4.0 & $27.0 \pm 0.71^{*}$ & $26.0 \pm 0.71$ & $27.0 \pm 0.71^{* * *}$ & $19.3 \pm 1.08$ \\
\hline \multicolumn{6}{|c|}{ Eucalyptus essential oil } \\
\hline 4 & 1.0 & $14.0 \pm 0.71^{* * * *}$ & $16.0 \pm 0.71$ & $11.3 \pm 1.08^{* *}$ & $13.0 \pm 1.41$ \\
\hline 5 & 2.0 & $18.0 \pm 0.71^{* *}$ & $20.0 \pm 0.71$ & $18.0 \pm 0.71$ & $18.0 \pm 0.71$ \\
\hline \multicolumn{6}{|c|}{ Clove essential oil } \\
\hline 6 & 1.0 & $11.3 \pm 1.08^{* * *}$ & $9.7 \pm 0.41^{* * *}$ & 0 & $10.0 \pm 0.71$ \\
\hline 7 & 1.5 & $14.0 \pm 0.71^{* * *}$ & $12.3 \pm 1.08^{* *}$ & $5.0 \pm 1.41^{* * *}$ & $14.0 \pm 1.41$ \\
\hline \multicolumn{6}{|c|}{ Cedar essential oil } \\
\hline 8 & 1.0 & $16.7 \pm 0.82^{* *}$ & $13.3 \pm 1.47^{*}$ & $14.0 \pm 0.71^{* *}$ & $12.7 \pm 1.08$ \\
\hline 9 & 1.5 & $18.0 \pm 0.71^{* *}$ & $20.3 \pm 0.41$ & $18.3 \pm 0.41$ & $16.7 \pm 1.08$ \\
\hline \multicolumn{6}{|c|}{ Tea tree essential oil } \\
\hline 10 & 1.5 & $19.7 \pm 0.41^{* *}$ & $15.0 \pm 0.71^{*}$ & $10.0 \pm 0.71^{* * *}$ & 0 \\
\hline 11 & 2.0 & $22.7 \pm 1.08$ & $18.3 \pm 0.82$ & $16.7 \pm 0.41$ & $9.7 \pm 2.16$ \\
\hline \multicolumn{6}{|c|}{ Chlorophyllipt oil solution } \\
\hline 12 & 0.5 & $17.0 \pm 0.71^{* *}$ & $18.3 \pm 0.41$ & $16.0 \pm 0.71^{*}$ & $16.0 \pm 0.71$ \\
\hline 13 & 1.0 & $26.7 \pm 1.78$ & $27.0 \pm 0.71$ & $24.0 \pm 0.71$ & $19.0 \pm 0.71$ \\
\hline \multicolumn{6}{|c|}{ "Clindamycin" } \\
\hline 14 (control) & 2.0 & $24.0 \pm 0.71$ & $19.3 \pm 1.08$ & $18.7 \pm 0.41$ & $13.7 \pm 2.48$ \\
\hline
\end{tabular}

Note: $*-\mathrm{P}<0.05 ; * *-\mathrm{P}<0.01 ; * * *-\mathrm{P}<0.001$ relative to control

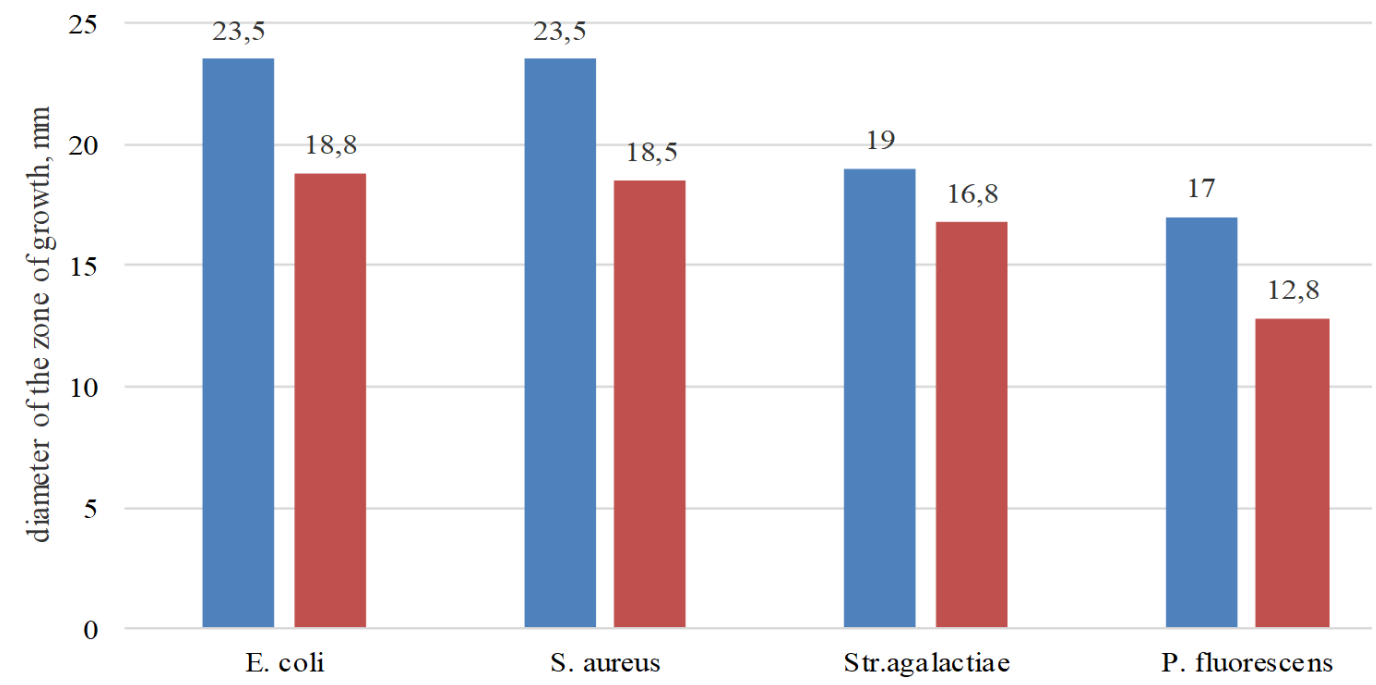

Fig. 1. Comparative analysis of the antimicrobial activity of the drug "Ointment for wounds" and "Clindamycin ointment $2 \%$ " (Clindamycin ointment $2 \%$ )

\section{Conclusions}

For the first time, a comparative study of the bactericidal action of essential vegetable oils of different composition, including $4 \%$ of Siberian pine essential oil, $2 \%$ of eucalyptus essential oil, $1.5 \%$ of carnation essential oil, $1.5 \%$ of cedar essential oil, $2.0 \%$ of tea tree essential oil and $1.0 \%$ of an oil solution of chlorophyllipt against standard test cultures of microorganisms. It was found that the bactericidal activity of our experimental drug under the conditionally named "Ointment for wounds" against S. aureus is twice higher $(\mathrm{P} \leq 0.05)$, compared with ointment based on clindamycin. Representatives of gram-negative microflora, in particular E. coli and $P$. fluorescens, were also very sensitive to it. The results of the antimicrobial activity of the experimental ointment based on the essential oil of Siberian pine, eucalyptus, carnation, cedar, tea tree and chlorophyllipt testify to the prospect of using herbal preparations for the treatment of skin diseases. After complete completion of preclinical and clinical trials, the drug with the proposed composition, it is advisable to introduce into production and veterinary practice.

\section{References}

Adnan, M. (2019). Bioactive potential of essential oil extracted from the leaves of Eucalyptus globulus (Myrtaceae). Journal of Pharmacognosy and Phytochemistry, 8(1), 213-216. http://www.phytojournal.com/archives/2019/vol8issue1/PartD/ 7-6-453-244.pdf. 
Bennouna, F., Lekbach, Y., Sadiki, M., El Abed, S., Koraichi, S.I., \& Lachkar, M. (2018). Antimicrobial efficacy of three essential oils against decaying cedar wood isolates. Research Journal of Microbiology, 13(2), 119-126. doi: 10.3923/jm.2018.119.126.

Bushuieva, I. V. (2013). Marketynhovi doslidzhennia rozvytku rynku veterynarnykh preparativ ta oblasti veterynarnoi farmatsii. [Marketing research on the development of the veterinary market and the field of veterinary pharmacy]. Zaporizkyi medychnyi zhurnal, 78(3), 90-93. http://nbuv.gov.ua/UJRN/ Zmzh 2013325 (in Ukrainian).

Carrión-Prieto, P., Martín-Gil, J., Fernández-Coppel, I. A., RuízPotosme, N. M., \& Martin-Ramos, P. (2018). Physicochemical studies of Siberian pine (Pinus sibirica) derived chewing gum. Trends in Phytochemical Research, 2(2), 119-124.

European committee on antimicrobial susceptibility testing breakpoint tables for interpretation of MICs and zone diameters. Version 7.1, valid from 2017-03-10. Available online at: http://www.eucast.org.

European committee on antimicrobial susceptibility testing antimicrobial susceptibility testing. EUCAST disk diffusion method. Version 5.0. January 2015. Available online at: www.eucast.org.

Gerecke, U. (2005). Market Opportunities in Natural and Alternative Animal Health Products. Richmond: T\&F Informa UK Ltd.

Harkat-Madouri, L., Asma, B., Madani, K., Said, Z.B.O., Rigou, P., Grenier, D., \& Boulekbache-Makhlouf, L. (2015). Chemical composition, antibacterial and antioxidant activities of essential oil of Eucalyptus globulus from Algeria. Industrial Crops and Products, 78, 148-153. doi: 10.1016/j.indcrop.2015.10.015.

Hong, E. J., Na, K. J., Choi, I. G., Choi, K. C., \& Jeung, E. B. (2004). Antibacterial and antifungal effects of essential oils from coniferous trees. Biological and Pharmaceutical Bulletin, 27(6), 863-866. doi: $10.1248 / \mathrm{bpb} .27 .863$.

Horiuk, Yu. V. (2018). Fagotherapy of cows mastitis as an alternative to antibiotics in the system of obtaining environmentally safe milk. Scientific Messenger of Lviv National University of Veterinary Medicine and Biotechnologies, 20(88), 42-47. doi: $10.32718 /$ nvlvet8807.

Li, M., Zhu, L., Liu, B., Du, L., Jia, X., Han, L., \& Jin, Y. (2016). Tea tree oil nanoemulsions for inhalation therapies of bacterial and fungal pneumonia. Colloids and Surfaces B: Biointerfaces, 141, 408-416. doi:10.1016/j.colsurfb.2016.02.017.

Okmen, G., Kardas, S., Bayrak, B., Arslan, A., \& Cakar, H. (2016). The antibacterial activities of Crocus sativus against mastitis pathogens and its antioxidant activities. WJPPS, 5(3), 146-156.
Queiroga, M. C., Pinto Coelho, M., Arantes, S. M., Potes, M. E., \& Martins, M. R. (2018). Antimicrobial activity of essential oils of Lamiaceae aromatic spices towards sheep mastitis-causing Staphylococcus aureus and Staphylococcus epidermidis. Journal of Essential Oil Bearing Plants, 21(5), 1155-1165. doi: 10.1080/0972060X.2018.1491330.

Santa Packyanathan, J., \& Prakasam, G. (2017). Antibacterial effect of clove oil against clinical strains of Escherichia coli. Journal of Pharmaceutical Sciences and Research, 9(7), 12031204. https://www.jpsr.pharmainfo.in/Documents/Volumes/ vol9Issue07/jpsr09071734.pdf.

Santos, E. M. S., Almeida, A. C., Santos, H. O., Cangussu, A. R., Costa, K. S., Alves, J. N., Barbosa L. C. B., \& Aguiar, R. W. S. (2019). Mechanism of Brassica oleracea performance in bovine infectious mastitis by bioinformatic analysis. Microbial pathogenesis, 129, 19-29. doi: 10.1016/j.micpath.2019.01.029.

Shaheen, M., Tantary, H. A., \& Nabi, S. U. (2016). A treatise on bovine mastitis: disease and disease economics, etiological basis, risk factors, impact on human health, therapeutic management, prevention and control strategy. Advances in Dairy Research, 10(1), 150. doi: 10.4172/2329-888X.1000150.

Shpatov, A. V., Popov, S.A., Salnikova, O.I., Kukina, T.P., Shmidt, E.N., \& Um, B.H. (2017). Composition and bioactivity of lipophilic metabolites from needles and twigs of Korean and Siberian Pines (Pinus koraiensis Siebold \& Zucc. and Pinus sibirica Du Tour). Chemistry \& biodiversity, 14(2), e1600203. doi: $10.1002 /$ cbdv.201600203.

Smith, A.C., Wood, C.L., McQuerry, K.J., \& Bewley, J.M. (2014). Effect of a tea tree oil and organic acid footbath solution on digital dermatitis in dairy cows. Journal of dairy science, 97(4), 2498-2501. doi: 10.3168/jds.2013-6776.

Tamminen, L. M., Emanuelson, U., \& Blanco-Penedo, I. (2018). Systematic review of phytotherapeutic treatments for different farm animals under European conditions. Frontiers in veterinary science, 5, 140. doi: 10.3389/fvets.2018.00140.

Vorobets, N. M., Kryvtsova, M. V., Rivis, O. Y., Spivak, M. Y., Yavorska, H. V., \& Semenova, H. M. (2018). Antimicrobial activity of phytoextracts on opportunistic oral bacteria, yeast and bacteria from probiotics. Regulatory Mechanisms in Biosystems, 9(3), 374-378. doi: 10.15421/021855.

Wolski, T., Najda, A., Kędzia, B., \& Wolska-Gawron, K. (2017). Phytotherapy of dermatological diseases. Postepy Fitoterapii, 4, 298-308. doi: 10.25121/PF.2017.18.4.298. 